\title{
A Study of Viral Marketing on Social Network in Stream Line Business Model of Data Mining in Management
}

\author{
S. Muthumari \\ Head \& Assistant Professor, Department of Management, \\ Sri Vasavi College,(Self-Finance Wing), Tamil Nadu, India \\ E-Mail: muthuparkavi@gmail.com
}

\begin{abstract}
Viral marketing and viral advertising refer to marketing techniques that use pre-existing social networks to produce exponential increases in brand awareness, through self-replicating viral processes, analogous to the spread of a computer virus. It can be often word-of-mouth delivered and enhanced online harness the network effect of the Internet and is very useful in reaching a large number of people very fast. The ultimate goal of marketers interested in creating successful viral marketing programs is to create viral messages that appeal to individuals with high social networking potential (SNP) and that have a high probability of being presented and spread by these individuals and their competitors in their communications with others in a short period of time. There are several sources of social networks where our model can be applied to, and a few are: Facebook, Twitter, LinkedIn, YouTube, Google+, Instagrams, online forums, email mailing lists.

Keywords:Viral Marketing,Social Networks, Viral Online Marketing, Internet, Viral Marketing Strategies \& Advertising Service, Business Model, Data Mining
\end{abstract}

\section{INTRODUCTION}

The attraction of viral marketing as well as challenges associated with viral marketing campaigns and different viral techniques including blogs and social networking, it examines different usersawareness, approaches and features of viral marketing. It can be delivered by word of mouth or enhanced by the network effects of the Internet and mobile networks. Viral marketing may take the form of videoclips interactive flash games, avenger's games, ebooks, brandableSoftware, images, text messages, email messages, or WebPages.

It is claimed that a customer tells an average of three people about a product or service he / she likes, and eleven people about a product or service which he / she did not like. Viral marketing is based on this natural human behaviour. Viral marketing as electronic word-of-mouth where by some form of marketing message related to a company, brand or products is transmitted is an exponentially growing way, often through the use of social network application.

Viral marketing has two defining elements.

The first is a growth or reproduction, rate greater than one; this implies that each receiver passes the message to more than one other person. For example, when initially seeded to one person, a viral marketing message with a reproduction rate of two would be transferred to 2,4,8,16,32, 64 etc. new people in the following periods. The second characteristic usually associated with viral marketing is use of social media applications Social media can be defined as "a group of internet- based applications that build on the ideological and technological foundations of web2.0, It is an umbrella term describing different type of applications such as collaborative projects(e.g. Wikipedia),blogs/ micro- blogs (Kaplan and Haenlein, is press), content communities(e.g. YouTube), social networking sites(e.g. face book),

\section{OBJECTIVES OF THE STUDY}

1. To study the viral marketing take advantage of socialnetworks influences among customers and achieve large changes in behavior.

2. To analyze the impact of viral marketing through spreading, reaching and purchasing.

3. To identify the common problems faced by the consumers in using viral marketing through social network and other technologies.

4. To study the online users awareness and time spent on social networks

5. To suggest the data mining used in business model of viral marketing through advanced technology.

\section{STATEMENT OF THE PROBLEM}

Viral marketing is a fast growing marketing activity in Tamilnadu. The emergence of foreign players like flipkart, amazon.com, snap deal etc. have intruded in the minds of youths, and middle aged segments who have frequently utilizing the internet web resources. The strategy of discount price model attracted the consumers to purchase the requirements through viral-marketing. The beneficiaries have spread the message to the well wishers friends and family members about the quality of the products as well as the price of the goods, There are several sources of social networks where our model can be applied to, and a few are: Facebook, Twitter, LinkedIn, YouTube, Google+, Instagrams, online forums, email mailing lists.

\section{VIRAL MARKETING AND SOCIAL NETWORKS}

The objective behind any marketing strategy is to create brand visibility and awareness. The term 'viral Marketing' 
popularized by Mr.JeffreyReport in 1996 and the term implies it is a way of spreading your message .Viral marketing is new the emerging marketing tool which uses social networking to spread the message Vasu Deva [8]. Viral marketing and viral advertising refer to marketing techniques that use pre-existing social networks to produce exponential increases in brand awareness, through selfreplicating viral processes, analogous to the spread of pathological computer viruses. It can be word of mouth delivered or enhanced by the network effects of the Internet Viral marketing facilitates and encourages people to pass along a marketing message voluntarily. Mohammed Rafi A.\& Fisher,RobertJ [12]Viral promotions may take the forms of funny video clips, interactive flash games, adventure games, images,SMS text messages.

1. Off -line- Word - of-Mouth

2. Online - Word - of-Mouse(Viral marketing)

Both the traditional word-of-mouth marketing and the viral marketing campaigns are carried out over social networks, and the existing literature of viral marketing over social networks has essential grown as research is being recently developed. Social network potential (SNP) is a numeric coefficient of computational algorithms to represent both the size of an individual's social network for the ability of individuals to influence the whole social network marketing.

Matthew Richardson and Pedro Domingos[7] Marketing has been one of the major applications of data mining decisions on whether or not to market to a particular person is based solely on their characteristics of direct marketing to which they belong to mass marketing leads to effect the members of a market have on others purchase decisions so viral marketing inexpensively to promote a product by marketing primarily to those with the strongest influence in the market.

Data mining techniques have been successfully employed for direct marketing $\mathrm{P}$. Dolningos and $\mathrm{M}$. Richardson[1]through by building models of predict future purchasing behaviour from past behaviour ,marketing could be more targeted and lead to increase in profit A.M. Hughes[2]so this modelthe market as a social network .viral marketing uses the customers in a market to promote product . Internet has over the past decade.millions of people interact with each other online, in many instances those social interactions are recorded in twenty years more and many online opportunities to mine social networksC. X. Ling and C. Li. [3] G. Piatetsky-Shapiro and B. Masand[4]of viral marketing .Usenet, newgroups, IRC ,instant messaging, online forums, emailing lists of possible sources of social networkS. Wasserman and K. Faust. Social Network Analysis [5].

Message customization, social network structure and customers' motive are salient antecedents that determine the spreading performance of the marketing information and communications. Some research on viral marketing schemes was carried out by the present authors based on Q Qusergroups between 2007 and 2008. Moreover, the simulation results reported and it was reveal that the email network of the users performing actual viral marketing activities is similar to a small-world network, regarding thebusiness information spreading behaviours.

\section{A. Propagation of Email Viruses}

A model of e-mail virus propagation of proposed in the email user be infected of user opens a virus contaminated email attachment and virus program will infect the user's computer and send itself as a new attachment to all email addresses existing in the user's computer address book. Using this model of emulationson spread the network's magnitude and initiator's degrees of the network were analyzed and address different socialnetworks with different viralmechanisms.

\section{B. Uses of Viral Marketing}

Viral marketing is effective for small as wellas medium sized business and any services SainiP.D.Marketing [11].Using Viral Marketing strategies one can market one's business and achieve all objectives including boosting sales, increasing revenue. The benefits includes like

1. Free advertising

2. Inexpensive to set-up

3. Quickly build your reputation

4. Hotmail,Cadbury

\section{The Important Techniques Used for Viral Marketing}

1. Online Advertising campaign

2. Blog marketing

3. Promotion of article

4. Development of viral contents

\section{Viral Marketing Transaction and Indian Perspectives}

FtoF F=Friends,family.forwarding e-visitors) India evolves differently as compared to other nations of internet preNetscape.com to post Netscape .com various stages are there

1. Pre-Netscape.com Usenet group social culture Indian.

2. Pre-Netscape.com boom sixdegrees.com, classmates,com, opinion.

3. Post Netscape.com.

Social networking and Viral marketing is effective through social networking reasons are everyone is using it, social media is gaining trust, it still growing, when one social network falls,another rises, social media is versatile, but in today's modern social networking is about connecting with people at a low cost with existing device and technology. It directly to reach the customers mind and to analyse the viral marketing awareness among the Indian users. 
The opinion of internet users about awareness about Ads on social media and findings are based on interviews conducted among customers. So maximum time is spent on internet for forwarding information, funny videos,profile related work only, low cost advertising through viral marketing and has started using social networking as a medium to promote.so it still a new concept. Some find it a waste of time online. Recommendation of users needs to learn the strategy of converting our friends to be customer and every individual should try to making advertisement for their business or professions.Try to take the usage of opportunities free social media connections and utilize it for awareness and one's own various benefits.Challenges of social networking like webtraffic,patchy connection, low penetration of computers and laptops, Trolling and internet bullying.

\section{CONCLUSION}

The data mining to improve viral marketing and apply techniques to data mined from real world knowledge sharing sites and efficiently to networks of hundreds of millions of customers. so techniques to handle continuously variable marketing actions and network knowledge Internet have many opportunities for small and medium size business to create new products and analyse new ways to market them. it leads to one man business now compete to equal with the multinational .so today more number of freelancers and small companies that specialize in marketing on the internet but Indian professionals need to synergize with fast effective dynamics of modern business model of viral marketing and social network.

\section{REFERENCES}

[1] P. Dolningos and M. Richardson, "Mining the Network Value of Customers", In Proceedings of the Seventh International Conference on Knowledge Discovery and Data Mining, San Francisco, CA, ACM Press, pp. 57-66, 2001.

[2] A. M. Hughes, "The Complete Database Marketer: Second Generation Strategies and Techniques for Tapping the Power of you Customer Database”, Irwin, Chicago, IL, 1996.

[3] C. X. Ling and C. Li, "Data mining for direct marketing: Problems and solutions", In Proceedings of the Fourth International
Conference on Knowledge Discovery and Data Mining, New York, NY, AAA I Press, pp. 73-79, 1998.

[4] G. Piatetsky-Shapiro and B. Masand, "Estimating campaign benefits and modeling lift", In Proceedings of the Fifth ACM SIGKDD International Conference on Knowledge Discovery and Data Mining, San Diego, CA, ACM Press, pp, 185-193, 1999.

[5] S. Wasserman and K. Faust, "Social Network Analysis: Methods and Applications”, Cambridge University Press, Cambridge, UK, 1994.

[6] S. Jurvetson, "What exactly is viral marketing? Red Herring", Vol. 78, pp. 110-112, 2000.

[7] Mining Knowledge-Sharing Sites for Viral Marketing Matthew Richardson and Pedro Domingos Department of Computer Science and Engineering University of Washington Box 352350 Seattle, WA 98195-2350 \{mattr, pedrod\} @ cs.washington.edu.

[8] Vasu Deva: E-marketing For Excellence, 2003.

[9] Vasu Deva: E-Business: search for Excellence, 2003.

[10] P. D. Saini, Marketing in 21st Century, 2010

[11] Mohammed Rafi A. \& Fisher, Robert J: Internet Marketing: Building avantagec in a Networked Economy, 2001.

[12] [Online] Available: www.facebook .com

[13] [Online] Available: www.myspace.info

[14] [Online] Available: www.crome.info

[15] M. Richardson and P. Domingos, "Mining Knowledge-Sharing Sites for Viral Marketing", SIGKDD02, Edmonton, Alberta, Canada, ACM, pp. 61-70, 2002.

[16] M. R. Subramani and P. Rajagopalan, "Knowledge-sharing and Influence in online Social Networks via Viral Marketing", Communications of the ACM, Vol. 46, No. 12, 2003.

[17] S. Banerjee, H. A. Qaheri, and A. E. Hassanien, "Mining Social Networks for Viral Marketing Using Fuzzy Logic", Computer Society Fourth Asia International Conference on Mathematical/Analytical Modeling and Computer Simulation,IEEE, pp. 24-28, 2010.

[18] S. Priya and K. M. Chinnadorai, "Viral Marketing", SMART Journal of Business Management Studies, Vol. 7, No. 1, pp.64-67, 2011.

[19] P. Shakarian and D. Paulo, "Large Social Networks can be Targeted for Viral Marketing with Small Seed Sets", ACM International Conference on Advances in Social Networks Analysis and Mining,IEEE, pp.1-8, 2012.

[20] S. Y. Bhat and M. Abulaish, "Overlapping Social Network Communicates and Viral Marketing”, International Symposium on Computational and Business Intelligence, IEEE, pp.243-246, 2013.

[21] Z. Zhu, "Discovering the Influential Users Oriental to Viral Marketing Based on Online Social Networks”, Elsevier,Science Direct, Physicaa, Vol. 392, pp.3459-3469, 2013.

[22] Anon, "The advantages and disadvantages of social networking. Every day-wisdom”, [Online] Available: http://www.everydaywisdom.com/social-networking.html, 2011

[23] D. Bryant, "The impact of viral marketing and reputation management”, 2010.

[24] C. Hutchings, "Commercial use of Facebook and Twitter - risks and rewards”, Business Horizons, Vol. 54, No. 3, pp. 193-207, 2012. 